\title{
Faktor-faktor yang Memengaruhi Sikap Mahasiswa Program Studi Psikologi, Keperawatan dan Kesejahteraan Sosial terhadap Perempuan Korban Perkosaan
}

\author{
Binahayati Rusyidi, Nunung Nurwati \\ Fakultas Ilmu Sosial dan Ilmu Politik, Universitas Padjadjaran \\ Email : binahayati@unpad.ac.id
}

\begin{abstract}
Abstrak
Pandangan atau sikap negatif serta menyalahkan perempuan yang menjadi korban tindak kekerasan seksual masih hidup dan berkembang di dalam masyarakat. Para penyedia layanan kesehatan dan sosial dituntut untuk memiliki sikap yang tepat terhadap korban tindak kekerasan seksual karena hal tersebut dapat memengaruhi akses dan efektivitas layanan. Tujuan penelitian adalah mendeskripsikan sikap mahasiswa tingkat sarjana terhadap perempuan korban perkosaan serta menguji asosiasi faktor-faktor sosial-demografi dan sosial-budaya terhadap sikap para mahasiswa. Responden adalah 318 mahasiswa semester 1, 3 dan 5 pada program studi kesejahteraan sosial, keperawatan dan psikologi di sebuah perguruan tinggi negeri di wilayah Jatinangor, Sumedang, Jawa Barat tahun. Penentuan sampel dilakukan secara non-random dengan menggunakan convenience sampling technique. Data dikumpulkan dari responden pada tahun 2015 dengan menggunakan kuesioner dan dianalisis secara statistik dengan teknik simple regressions. Umumnya mahasiswa menunjukkan sikap yang cenderung kurang positif terhadap korban kekerasan seksual. Hal ini antara lain ditunjukkan dengan masih kuatnya kecenderungan menyalahkan korban, kurang mempercayai kredibilitas korban, dan meremehkan kejadian perkosaan. Sikap terhadap peran jender, etnisitas dan tingkat keberagamaan merupakan faktor-faktor yang berasosiasi secara signifikan terhadap sikap mahasiswa. Mahasiswa yang mendukung kesetaraan peran laki-laki dan perempuan dalam kehidupan masyarakat dan keluarga, kelompok etnis non-Sunda, serta responden dengan tingkat keberagamaan yang lebih rendah cenderung melaporkan sikap yang lebih positif terhadap korban dibandingkan mereka yang bersikap konservatif terhadap peran jender, berasal dari etnis Sunda dan melaporkan tingkat keberagamaan yang lebih tinggi. Tidak ditemukan pengaruh program studi, jenis kelamin, usia dan waktu tempuh perkuliahan terhadap sikap mahasiswa.
\end{abstract}

Kata kunci: Faktor sosial demografis, faktor sosial budaya, korban perkosaan, sikap mahasiswa.

\section{Factors Influenced Attitudes of Students of Psychology, Nursing and Social Welfare Program towards the Raped Woman}

\begin{abstract}
Negative perception or stigma and blaming towards women experienced sexual harrastments remained staying and growing among the society. Health care and social providers needs to demonstrate supportive attitudes towards these victims since this may affect access and efficacy of services. This study aimed to describe the attitude of undergraduate students towards women who were being raped and to examine the relationship between social-demography and social-cultural towards the students' attitudes itself. 318 students were recruited using non-randomised convenience sampling technique from first, third and fifth years from social welfare study programe, nursing and psychology in a public university in Jatinangor, Sumedang, West Java. Data was collected using self-rating instrument and then analysed using simple regression. The majority of students have demonstrated unfavourable attitudes towards women who had sexual harrasments. Partipants have tended to blame the victims, to distrust the credibility of victims, and understimated the harrasment occurance. Attitudes towards gender role, etnicity, and diversity level were significantly associated with students' attitudes. Those who reported gender equality in the society and family, non-Sundanesse, and low diversity level, have tended to report more positive attitudes than those who have conservative view of gender roles, Sundanesse and high diversity level. No influences of education program, gender, age and length of study of the respondents were identified.
\end{abstract}

Keywords: Social demography, social-cultural, sexual harrasment, student's attitudes. 
Binahayati Rusyidi : Faktor yang Memengaruhi Sikap Mahasiswa terhadap Perempuan Korban Perkosaan

\section{Pendahuluan}

Kekerasan seksual terhadap perempuan merupakan salah satu permasalahan sosial serius di Indonesia. Laporan Komnas Perempuan (2013) menunjukkan bahwa dalam rentang waktu 1998-2010 terjadi 93.960 kasus kekerasan seksual terhadap perempuan atau hampir hampir $25 \%$ dari seluruh kasus kekerasan terhadap perempuan yang dilaporkan (400.939 kasus). Komnas Perempuan (2016) juga mencatat bahwa pada tahun 2015, kekerasan seksual merupakan bentuk kekerasan terhadap perempuan yang terbesar yang terjadi baik di ranah personal maupun komunitas.

Kekerasan seksual dalam bentuk perkosaan menimbulkan dampak yang signifikan terhadap korban baik secara fisik, psikologis, dan sosial. Perkosaan yang umumnya disertai dengan kekerasan dapat menimbulkan kematian atau kecacatan fisik pada korban, menyebabkan korban terjangkit penyakit menular seksual, atau kehamilan yang tidak dikehendaki. Korban perkosaan juga umumnya sangat rentan mengalami gangguan perilaku dan gangguan psikologis seperti gangguan kecemasan, depresi, eating disorder, posttraumatic stress disorder, gangguan tidur, dan percobaan bunuh diri (Campbell, 2008; Chen et al., 2010).

Namun dalam masyarakat masih banyak ditemui keyakinan-keyakinan terkait mitosmitos tentang perkosaan (rape myth). Konsep rape myth diperkenalkan oleh Martha Burt pada tahun 1980dandidefinisikansebagaiprasangka, stereotipe atau keyakinan-keyakinan yang salah tentang perkosaan, korban perkosaan dan pelaku perkosaan. Termasuk di dalamnya sikap yang menyalahkan korban, memandang enteng dampak perkosaan terhadap korban atau menilai korban sebagai pihak yang yang bertanggungjawab atas terjadinya terjadinya perkosaan, bukan pelaku. Meskipun persepsipersepsi tersebut tidak didukung oleh fakta, dalam kenyataannya, pandangan-pandangan tersebut masih diyakini dan bahkan dijadikan sandaran untuk menjustifikasi kekerasan terhadap perempuan oleh kaum laki-laki (Burt, 1980).

Berbagai studi menunjukkan bahwa sikap tidak simpatik yang ditunjukkan lingkungan berpengaruh terhadap pemulihan korban tindak kekerasan seksual. Misalnya, sikap menyalahkan korban yang ditunjukkan polisi, penyedia layanan kesehatan atau sosial kepada korban merupakan penghalang bagi korban untuk melaporkan kasus yang dialaminya, mencari bantuan profesional, mengurangi efektivitas layanan dan menghambat korban untuk mengatasi dampak negatif kekerasan seksual yang mereka alami (Goldblatt, 2009; Miller, Amacker, \& King, 2011). Oleh karena itu sangat penting bagi para penyedia layanan untuk menyadari sikap terhadap korban kekerasan seksual untuk menghindari terjadinya reviktimisasi terhadap korban (Maier, 2008).

Artikel ini menggali sikap mahasiswa program studi psikologi, keperawatan dan kesejahteraan sosial terhadap korban perkosaan serta menganalisis faktor-faktor yang memengaruhi sikap para mahasiswa di ketiga program studi tersebut. Para psikolog, perawat, dan pekerja sosial merupakan profesi yang berpeluang besar untuk terlibat dalam penyediaan layanan bagi korban tindak kekerasan seksual melalui layanan di rumah sakit, konseling, rumah aman, dan sebagainya. Mengingat besarnya peranan pendidikan dalam pembentukan sikap profesional, maka penting untuk memahami sikap para calon profesional tersebut dan memahami faktor-faktor yang memengaruhi sikap mereka terhadap korban kekerasan seksual. Informasi dan pemahaman mengenai sikap para mahasiswanya akan membantu lembaga pendidikan merancang proses pembelajaran dan pengembangan kompetensi yang dapat menunjang pembentukan sikap profesional calon penyedia layanan, khususnya dalam pelayanan korban tindak kekerasan.

Pentingnya penelitian ini juga untuk mempersempit kesenjangan pengetahuan mengenai sikap para calon profesional penyedia layanan kesehatan dan layanan sosial terhadap korban perkosaan di Indonesia. Selama ini berbagai studi yang dilakukan umumnya menyasar para mahasiswa perguruan tinggi di luar Indonesia seperti Amerika Serikat dan Australia (Newcombe, Eynde, Hafner, \& Jolly, 2008; Talbott, Neill, \& Rankin, 2010; Baldwin-White \& Elias-Labort, 2016), dan Korea Selatan (Lee, Busch-Armendaris, Kim, \& Lim, 2007; Lee, Lee, \& Lee, 2012).

Dalam memahami faktor-faktor yang 
Binahayati Rusyidi : Faktor yang Memengaruhi Sikap Mahasiswa terhadap Perempuan Korban Perkosaan

memengaruhi sikap terhada perempuan korban tindak kekerasan seksual, maka penelitian ini menggunakan kombinasi pendekatan teoritis pemikiran feminis dan sosiologis. Perspektif feminis menggarisbawahi pengaruh ideologi patriarki yang melegitimasi dominasi lakilaki atas kaum perempuan, termasuk melalui kekerasan seksual. Dengan demikian sikap terhadap kekerasan seksual atau korban tindak kekerasan seksual akan terkait dengan keberpihakan atau ketidakberpihakan terhadap ideologi patriarki atau ketidaksetaraan jender (Yllo \& Strauss, 1990; Boakye, 2009). Sementara itu perspektif sosiologis berpandangan bahwa faktor-faktor sosialdemografis dan struktural memengaruhi sikap atau persepsi seseorang. Flood dan Pase (2009) berargumen bahwa faktor sosial demografis seperti usia, pendidikan, latar belakang keluarga, dan sebagainya berasosiasi terhadap cara pandang seseorang terhadap fakta sosial tertentu termasuk kekerasan seksual.

\section{Metode Penelitian}

Penelitian pada penelitian ini menggunakan pendekatan kuantitatif. Populasi penelitian adalah mahasiswa program Sarjana semester 1, 3, dan 5 pada program studi Keperawatan (Fakultas Keperawatan), Psikologi (Fakultas Psikologi) dan Kesejahteraan Sosial (Fakultas Ilmu Sosial dan Ilmu Politik) pada sebuah perguruan tinggi negeri di wilayah Sumedang Jawa Barat. Pemilihan responden dilakukan secara non-random dengan teknik non convenience sampling. Setelah berkoordinasi dengan dosen-dosen di ketiga program studi tersebut, peneliti mendatangi para calon responden yang sedang mengikuti perkuliahan di kelas dan menawarkan mereka untuk berpartisipasi dalam survey. Mahasiswa yang bersedia berpartisipasi dalam survey selanjutnya akan diminta membaca Informed Consent dan jika bersedia maka mereka akan diminta untuk mengisi kuesioner seusai perkuliahan pada hari yang sama. Dalam penelitian ini, peneliti mendatangi masingmasing 3 (tiga) kelas per program studi dalam beberapa hari yang berbeda guna mendapatkan jumlah respoden yang representatif di setiap cohort. Pengumpulan data dilakukan di akhir tahun 2015.

Variabel terikat (dependent variable) dalam penelitian ini adalah sikap terhadap korban korban perkosaan. Pengukuran dilakukan menggunakan Attitudes toward Rape Victims Scale. Attitudes toward Rape Victims Scale (ATWRVS) terdiri atas 25 item pernyataan untuk menggali sikap anggota masyarakat yang diharapkan (positif) atau tidak diharapkan (negatif) terhadap korban tindak perkosaan, utamanya menyangkut aspek-aspek menyalahkan korban (victim blame), kredibilitas korban (credibility), kelayakan program mengalami perkosaan (deservingness), fitnah terhadap korban (denigration) dan pandangan yang menganggap enteng kejadian perkosaan (trivialization).

ATVRS menggunakan 5 skala Likert (1=sangat tidak setuju, $2=$ tidak setuju, $3=$ netral, 4=setuju, dan 5=sangat setuju). Dalam skala tersebut terdapat 8 pernyataan positif (item 3,5,7,10, 12, 15, 19, dan 22) dan sisanya sebanyak 17 pertanyaan negatif. Dalam analisis, skoring terhadap pernyataanpernyataan positif dibalik. Misalnya, apabila responden menjawab setuju (=4) pada salah satu pernyataan positif, maka skornya dibalik menjadi $=2$, dan seterusnya. Rentang total skor 25 (terendah) hingga 125 (tertinggi). Semakin rendah skor yang diperoleh berarti semakin positif sikap responden terhadap korban perkosaan dan sebaliknya semakin tinggi skor berarti semakin negatif sikap responden terhadap korban kekerasan seksual (Ward, 1992). Skala ATVR sudah banyak digunakan dalam berbagai penelitian, termasuk untuk populasi masyarakat di negara-negara Asia dan memiliki tingkat reliabilitas yang baik ( Ward, 1992). Dalam penelitian ini, reliabilitas ATVR tergolong cukup yaitu .70.

Variabel bebas dalam penelitian ini adalah variabel-variabel yang dikategorikan sebagai kelompok sosial demografis dan sosial budaya seperti jenis kelamin, program studi, semester, usia, suku bangsa, agama, tingkat keberagamaan (reliogisity), dan sikap terhadap peran jender. Pengukuran sikap terhadap peran jender menggunakan instrumen Attitudes Toward Women Scale short version yang terdiri dari 15 pernyataan yang mengases sikap individu terkait hak-hak, peran-peran dan 
Binahayati Rusyidi : Faktor yang Memengaruhi Sikap Mahasiswa terhadap Perempuan Korban Perkosaan

kewajiban-kewajiban perempuan dan laki-laki dalam masyarakat modern (misal: kaum lakilaki yang harus memegang kepemimpinan dalam masyarakat). Pengukuran ATWS menggunakan 4 poin Likert Scale dengan rentang skor total 15 (terendah) hingga 60 (tertinggi). Semakin tinggi skor berarti mendukung kesetaraan peran laki-laki dan perempuan dalam kehidupan masyarakat sedangkan skor yang semakin rendah menunjukkan sikap yang kurang mendukung kesetaraan jender (Helmreich, Spence, \& Gibson, 1982). Instrumen ATWS telah divalidasi dalam berbagai populasi penelitian di banyak negara termasuk Asia dan memiliki reliabilitas yang baik (Boakye, 2009). Dalam penelitian ini tes internal reliability ATWS menunjukkan skor yang cukup baik yaitu 0,70 .

Sementara itu tingkat keberagamaan diukur dengan menggunakan Religiosity Scale (Haj-Yahia, 1998). Religiosity Scale (RS) terdiri atas 3 pertanyaan untuk mengukur tingkat keberagamaan individu (misal:tingkat komitmen melaksanakan ibadah yang diwajibkan agama) yang pengkurannya menggunakan 6 poin Likert Scale. Semakin tinggi skor total berarti semakin tinggi tingkat keberagamaan seseorang dan sebaliknya. Religiosity Scale telah divalidasi dengan sampel penelitian di berbagai negara termasuk Timur Tengah dan Indonesia dengan internal reliability yang baik (Haj-Yahia \& Sadan, 2008; Ruyidi, 2011). Dalam penelitian ini, internal reliability $\mathrm{RS}$ cukup baik, yaitu 0,75 .

Analisis data pada penelitian ini dilakukan dengan menggunakan Statistical Package for the Social Sciences (SPSS) versi 22. Analisis statistik yang digunakan meliputi analisa deskriptif, bivariate, dan simple regressions. Analisis statistik utama yang akan dilakukan adalah simple regressions yang memungkinkan pengujian terkait tingkat pengaruh suatu variabel bebas terhadap suatu variabel terikat ketika variabel bebas lainnya dikontrol. Peneliti juga melakukan analisis pre-regression dan hasilnya menunjukkan bahwa asumsi normalitas dan linearitas terpenuhi. Uji multikolinearitas menunjukkan tidak terdapat hubungan linear yang kuat di antara beberapa variabel bebas yang diuji di dalam model regresi. Uji autokorelasi melalui analisa scatter plot menunjukkan tidak terdapat heterokesatisitas dan pengecekan P-P plot menunjukkan bahwa sebaran data residual memenuhi asumsi normalitas (Tabachnick \& Fidell, 2007).

Prosedur etik diterapkan dalam penelitian ini. Lembar Kesediaan (Informed Consent) menjelaskan bahwa studi bersifat anonim, keikutsertaan peserta bersifat sukarela; bahwa keikutsertaan/ketidaksertaan dalam studi tidak akan memengaruhi hak dan kewajiban mahasiswa, serta pernyataan bahwa pertanyaan-pertanyaan yang diajukan diantisipasi tidak menimbulkan kerugian, kesulitan atau masalah bagi para responden. Masing-masing responden diminta untuk mengisi kuesioner di dalam kelas dan setelah selesai langsung mengumpulkannya kepada petugas lapangan

\section{Hasil Penelitian}

Karakteristik sosial-demografis responden digambarkan secara detil dalam tabel 1 di bawah ini. Sebanyak 318 (tiga ratus delapan belas) mahasiswa program Sarjana yang sedang studi pada semester 1, 3 dan 5 pada program studi Psikologi, Keperawatan, dan Kesejahteraan Sosial berpartisipasi dalam penelitian. Rentang usia responden adalah 17 hingga 39 tahun dengan usia rata-rata 20 tahun. Proporsi responden berdasarkan program studi relatif berimbang yaitu masing-masing sekitar 30\%. Namun demikian, sebagian besar responden $(85 \%)$ adalah perempuan. Hal ini sejalan dengan fakta bahwa ketiga program studi yang disasar dalam penelitian ini umumnya memang lebih diminati mahasiswa perempuan, khususnya program studi keperawatan.

Sebagian besar responden adalah Muslim (91\%) dan mengingat proporsi responden responden yang beragama Islam sangat tidak seimbang dengan kelompok agama lainnya, maka variabel agama tidak dimasukkan dalam analisis lanjutan. Etnisitas responden cukup beragam namun lebih didominasi oleh suku Sunda (53\%) dan Jawa (25\%). Oleh karena itu dalam analisis, etnisitas dipersempit menjadi 2 kelompok besar yaitu Sunda dan non-Sunda (Jawa, Minang, Batak, Bugis, Betawi, dll). 
Binahayati Rusyidi : Faktor yang Memengaruhi Sikap Mahasiswa terhadap Perempuan Korban Perkosaan

Tabel 1 Karakteristik Sosial Demografis Responden $(n=318)$

\begin{tabular}{lcc}
\hline \multicolumn{1}{c}{ Variabel } & Frekuensi & Persentase (\%) \\
\hline Program Studi/Fakultas & & 30,80 \\
Kesejahteraan Sosial (FISIP) & 98 & 37,70 \\
Keperawatan (Keperawatan) & 120 & 31,50 \\
Psikologi (Psikologi) & 100 & \\
Jenis kelamin & & 15,00 \\
Laki-laki & 47 & 85,00 \\
Perempuan & 271 & \\
Semester & & 42,50 \\
Satu & 135 & 20,10 \\
Tiga & 64 & 37,40 \\
Lima & 119 & \\
Agama & & 91,50 \\
Islam & 291 & 8,50 \\
Lainnya (Katolik, Protestan, Hindu) & 26 & 53,60 \\
Suku Bangsa & & 46,40 \\
Sunda & 143 & \\
Non Sunda & 165 & \\
\hline
\end{tabular}

Sikap mahasiswa terhadap korban perkosaan dapat dilihat pada tabel 2 yang menunjukkan respon mahasiswa terhadap pernyataan-pernyataan yang mengukur sikap responden terhadap perempuan korban perkosaan. Untuk kepentingan analisis, prosentase setuju dan sangat setuju digabungkan menjadi satu sebagai respon setuju, demikian pula sebaliknya prosentase jawaban tidak setuju dan sangat tidak setuju sebagai kategori tidak setuju.

Analisis deskriptif menunjukkan bahwa secara umum, sikap mahasiswa terhadap korban tindak kekerasan cenderung ke arah kurang positif seperti ditunjukkan dengan rata-rata mean $(\mathrm{M}=3.30)$. Respon positif ditunjukkan oleh sebagian besar responden hanya pada beberapa pernyataan. Misalnya, $81 \%$ responden menyatakan tidak setuju bahwa perempuan secara diam-diam berharap menjadi korban perkosaan $(\mathrm{M}=1.56), 75 \%$ mahasiswa menolak pernyataan bahwa perempuan yang sudah pernah melakukan hubungan seks sebaiknya tidak melaporkan kasus perkosaan yang terjadi ( $\mathrm{M}=1.89), 73 \%$ tidak setuju bahwa dalam sebagian besar kasus perkosaan terjadi karena perempuan korban pantas mendapatkannya ( $\mathrm{M}=1.94)$, dan $67 \%$ menyatakan ketidaksetujuan mereka bahwa perkosaan membawa kebaikan kepada korban $(\mathrm{M}=1.94)$.

Sebaliknya, respon negatif atau tidak diharapkan terhadap korban dan tindak kekerasan seksual lebih dominan dibandingkan respon positif. Misalnya, sebagian besar responden menyatakan persetujuan bahwa perkosaan disebabkan oleh perilaku atau kesalahan korban seperti memakai baju ketat atau rok mini $(82 \%, \mathrm{M}=4.12)$, mengkonsumsi alkohol $(75 \%, \quad M=3.97)$, atau bepergian sendiri di malam hari $(75 \%, M=3.86)$. Hal ini sejalan dengan temuan bahwa $62 \%$ responden tidak setuju bahwa menjadi korban kekerasan seksual dapat dialami wanita "baik-baik" atau "tidak baik" $(\mathrm{M}=3.65)$. Hanya sekitar 20\% setuju untuk tidak meragukan keabsahan laporan perkosaan yang dilakukan oleh perempuan 'tidak baik' seperti penari erotis, pekerja seks $(\mathrm{M}=3.30)$ atau menempatkan laki-laki sebagai pihak yang bertanggungjawab dalam perkosaan seorang wanita.

Selanjutnya, sebagian besar responden masih cenderung memandang remeh kejadian perkosaan atau cenderung meragukan kredibilitas korban. Misalnya, secara berurutan hanya $26 \%$ dan kurang dari $20 \%$ responden tidak setuju bahwa perkosaan dianggap valid terjadi jika korban menunjukkan tingkat 
Binahayati Rusyidi : Faktor yang Memengaruhi Sikap Mahasiswa terhadap Perempuan Korban Perkosaan

perlawanan yang memadai $(\mathrm{M}=3.25)$ dan korban berbohong mengaku diperkosa ketika menemukan dirinya hamil $(\mathrm{M}=3.11)$. Selanjutnya $60 \%$ setuju jika perempuan yang sehat dapat mencegah terjadinya perkosaan jika korban benar-benar melakukan perlawanan $(\mathrm{M}=3.62)$ dan kurang dari 14\% mendukung bahwa pengakuan diperkosa oleh korban bukan karena korban marah atau balas dendam ke pelaku (M=3.30). Enam puluh tujuh persen juga setuju bahwa korban perkosaan bernilai rendah $(\mathrm{M}=3.25)$. Penelitian juga menemukan bahwa masih terdapat sikap yang ambigu di kalangan mahasiswa, umumnya terkait kredibilitas korban. Misalnya, lebih dari 45\% responden menunjukkan ambivalensi terhadap pernyataan bahwa banyak perempuan yang mengarang cerita telah diperkosa ketika mengetahui bahwa dirinya hamil (di luar pernikahan) atau berbohong mengaku diperkosa karena kemarahan atau dendam kepada pelaku.

Analisis multivariate analysis dengan menggunakan simple multiple regressions

Tabel 2 Distribusi Respon Mahasiswa terhadap Korban Perkosaan (\%)

\begin{tabular}{|c|c|c|c|c|c|}
\hline Pernyataan & STS & TS & $\mathbf{N}$ & $\mathbf{S}$ & SS \\
\hline Korban perkosaan bernilai rendah & 0.9 & 3.5 & 28.4 & 34.1 & 33.1 \\
\hline $\begin{array}{l}\text { Tingkat perlawanan perempuan menjadi faktor utama yang menentukan } \\
\text { bahwa perkosaan memang terjadi }\end{array}$ & 9.1 & 17 & 27.1 & 32.8 & 13.9 \\
\hline Korban perkosaan umumnya tidak bersalah & 14.5 & 25.2 & 29.3 & 26.8 & 4.1 \\
\hline Korban umumnya mengaku diperkosa agar tidak dipersalahkan & 10.4 & 21.2 & 42.4 & 20.3 & 5.7 \\
\hline Wanita 'baik' atau 'tidak baik' bisa menjadi korban perkosaan & 27.3 & 34.6 & 9.8 & 19.4 & 8.9 \\
\hline $\begin{array}{l}\text { Perempuan yang sudah pernah melakukan hubungan seks sebaiknya } \\
\text { tidak melaporkan kasus perkosaan yang terjadi }\end{array}$ & 52.8 & 21.2 & 14.9 & 6 & 5.1 \\
\hline $\begin{array}{l}\text { Tingkahlaku atau penampilan perempuan tidak menyebabkan terjadinya } \\
\text { perkosaan }\end{array}$ & 30.3 & 38.5 & 11 & 13.6 & 6.6 \\
\hline $\begin{array}{l}\text { Perempuan yang berada di bawah pengaruh alkohol biasanya bersedia } \\
\text { melakukan hubungan seks }\end{array}$ & 3.5 & 3.8 & 17.4 & 43.4 & 31.6 \\
\hline Perkosaan memberi kebaikan bagi korban & 56.3 & 11.1 & 19.6 & 8.5 & 4.4 \\
\hline $\begin{array}{l}\text { Perempuan yang merasa bersalah karena melakukan hubungan seks } \\
\text { di luar pernikahan kemungkinan tidak memalsukan perkosaan yang } \\
\text { dialaminya }\end{array}$ & 6.6 & 20.3 & 54.7 & 13.6 & 4.7 \\
\hline Sebagian besar perempuan diam-diam berharap diperkosa & 70.3 & 10.7 & 13.9 & 3.2 & 1.9 \\
\hline Perempuan mana saja bisa jadi korban perkosaan & 55.8 & 28.4 & 8.5 & 3.2 & 4.1 \\
\hline $\begin{array}{l}\text { Wajar saja perempuan diperkosa jika menumpang kendaraan orang yang } \\
\text { tidak dikenal }\end{array}$ & 28.8 & 23.1 & 15.5 & 27.5 & 5.1 \\
\hline $\begin{array}{l}\text { Banyak perempuan mengarang cerita telah diperkosa ketika mengetahui } \\
\text { bahwa mereka hamil }\end{array}$ & 7.3 & 12.3 & 47.5 & 28.2 & 4.7 \\
\hline Laki-laki harus bertanggungjawab atas terjadinya perkosaan & 17.8 & 32.4 & 29.5 & 16.2 & 4.1 \\
\hline $\begin{array}{l}\text { Perempuan yang bepergian sendiri malam hari mengundang terjadinya } \\
\text { perkosaan }\end{array}$ & 1.6 & 9.2 & 13.6 & 52.8 & 22.8 \\
\hline $\begin{array}{l}\text { Banyak perempuan mengklaim telah diperkosa jika pada awalnya } \\
\text { mereka bersedia melakukan hubungan seks, namun kemudian berubah } \\
\text { fikiran dan menolaknya }\end{array}$ & 4.4 & 16.8 & 53.8 & 22.2 & 28 \\
\hline $\begin{array}{l}\text { Tuduhan telah diperkosa oleh perempuan yang bekerja di bar, penari } \\
\text { erotis dan pekerja seks harus dicurigai kebenarannya }\end{array}$ & 4.7 & 15.8 & 33.2 & 37.3 & 8.9 \\
\hline Korban perkosaan sebaiknya tidak menyalahkan diri sendiri & 10.1 & 46.2 & 30.7 & 10.8 & 2.2 \\
\hline $\begin{array}{l}\text { Seorang perempuan sehat akan berhasil menggagalkan perkosaan jika } \\
\text { mereka benar-benar melawan pelaku }\end{array}$ & 2.5 & 13.3 & 24.1 & 39.6 & 20.6 \\
\hline $\begin{array}{l}\text { Banyak perempuan berbohong bahwa mereka diperkosa karena } \\
\text { kemarahan atau dendam kepada tertuduh }\end{array}$ & 3.2 & 10.4 & 45.9 & 34.2 & 6.3 \\
\hline
\end{tabular}


Binahayati Rusyidi : Faktor yang Memengaruhi Sikap Mahasiswa terhadap Perempuan Korban Perkosaan

\begin{tabular}{|c|c|c|c|c|c|}
\hline Pernyataan & STS & TS & $\mathbf{N}$ & $\mathbf{S}$ & SS \\
\hline $\begin{array}{l}\text { Perempuan yang memakai baju ketat atau rok mini tidak } \\
\text { mengundang terjadinya perkosaan }\end{array}$ & 49.4 & 32.6 & 5.4 & 6.3 & 6.4 \\
\hline $\begin{array}{l}\text { Perempuan yang menempatkan diri pada sitausi berisiko memilki } \\
\text { keinginan di bawah sadar bersedia diperkosa }\end{array}$ & 37.0 & 23.7 & 28.5 & 8.5 & 2.2 \\
\hline $\begin{array}{l}\text { Perempuan yang memiliki pengalaman seksual tidak terpengaruh } \\
\text { negative oleh perkosaan yang dialaminya }\end{array}$ & 21.6 & 31.4 & 31.4 & 14 & 1.6 \\
\hline $\begin{array}{l}\text { Dalam sebagian besar kasus, perkosaan terjadi karena perempuan } \\
\text { korban pantas mendapatkannya }\end{array}$ & 36.8 & 36.2 & 22.2 & 4.1 & .6 \\
\hline
\end{tabular}

Tabel 3 Hasil Analisis Simple Regressions Asosiasi Faktor-Faktor Sosial Demografis dan Sosial Budaya terhadap Sikap terhadap Korban Perkosaan

\begin{tabular}{|c|c|c|c|c|c|}
\hline \multirow{2}{*}{ Model } & \multicolumn{2}{|c|}{ Unstandardized Coefficients } & \multirow{2}{*}{$\begin{array}{c}\begin{array}{c}\text { Standardized } \\
\text { Coefficients }\end{array} \\
\text { Beta }\end{array}$} & \multirow[t]{2}{*}{$\mathbf{t}$} & \multirow[t]{2}{*}{ Sig. } \\
\hline & B & Std. Error & & & \\
\hline (Constant) & 77.300 & 4.826 & & 16.016 & .000 \\
\hline $\begin{array}{l}\text { Program studi1 } \\
\text { (keperawatan \& KS) }\end{array}$ & .419 & 1.587 & .022 & .264 & .792 \\
\hline $\begin{array}{l}\text { Program studi } 2 \\
\text { (keperawatan \& } \\
\text { psikologi) }\end{array}$ & -2.199 & 1.313 & -.112 & -1.675 & .095 \\
\hline Semester & -.110 & .364 & -.022 & -.302 & .763 \\
\hline $\begin{array}{l}\text { Jenis kelamin } \\
(\text { perempuan=1) }\end{array}$ & -2.412 & 1.455 & -.093 & -1.658 & .098 \\
\hline Usia & -.110 & .131 & -.051 & -.838 & .403 \\
\hline Suku bangsa (Sunda=1) & 3.339 & 1.022 & .186 & 3.267 & .001 \\
\hline $\begin{array}{l}\text { Sikap terhadap peran } \\
\text { jender }\end{array}$ & -.325 & .079 & -.236 & -4.118 & .000 \\
\hline Tingkat keberagamaan & .652 & .222 & .166 & 2.936 & .004 \\
\hline
\end{tabular}

Dependent variable: Sikap Terhadap Korban Perkosaan

menemukan terdapat 3 (tiga) variabel yang berasosiasi signifikan dengan sikap mahasiswa terhadap korban perkosaan. Sebagaimana digambarkan dalam tabel 3, berdasarkan tingkat pengaruhnya, prediktor yang paling berpengaruh adalah sikap terhadap peran jender, etnisitas, dan tingkat keberagamaan. Semakin egaliter sikap mahasiswa terhadap peran gender maka semakin positif sikap mereka terhadap korban kekerasan seksual $(\mathrm{t}=$ - 4.118, $\mathrm{p}=.000$ ) ketika variabel independen lainnya dikontrol. Penelitian juga menemukan bahwa responden mahasiswa yang berlatar belakang suku Sunda melaporkan sikap yang lebih negatif terhadap korban perkosaan dibandingkan dengan mahasiswa yang berlatar belakang suku bangsa non-Sunda $(\mathrm{t}=3.267$, $p=0.001)$ ketika variabel idependen lainnya dianggap konstan. Selanjutnya, semakin tinggi tingkat keberagamaan yang dilaporkan responden, maka akan semakin negatif sikap mereka terhadap korban $(\mathrm{t}=2.936, p=0.004)$ ketika variable independen lainnya dikontrol.

Penelitian tidak menemukan asosiasi yang signifikan antara program studi, semester, jenis kelamin, dan usia dengan sikap mahasiswa terhadap korban kekerasan seksual. Dengan kata tidak terdapat perbedaan sikap terhadap korban perkosaan di antara mahasiswa kesejahteraan sosial, keperawatan dan psikologi. Lama studi juga tidak memengaruhi sikap, demikian pula halnya jenis kelamin. Selanjutnya, meskipun penelitian menunjukkan bahwa sikap terhadap korban kekerasan seksual semakin positif dengan dengan pertambahan usia responden, perbedaan yang ditunjukkan tidak signifikan.

Nilai $R$ square dari analisis yang dilakukan 
Binahayati Rusyidi : Faktor yang Memengaruhi Sikap Mahasiswa terhadap Perempuan Korban Perkosaan

adalah 0.185 ; menunjukkan bahwa $18.5 \%$ variance pada sikap terhadap korban perkosaan (dependent variable) dijelaskan oleh variabel sosio demografis dan sosial budaya yang diuji dalam penelitian ini. Ini berarti, lebih dari $80 \%$ variance pada dependen variabel dapat dijelaskan oleh variabel-variabel bebas lainnya yang tidak diuji dalam studi ini.

\section{Pembahasan}

Penelitian ini menemukan bahwa umumnya sikap para mahasiswa program studi kesejahteraan sosial, psikologi dan keperawatan cenderung kurang simpatik terhadap korban perkosaan. Mayoritas responden mendukung pernyataan bahwa perkosaan terhadap perempuan adalah sesuatu yang buruk, tidak diharapkan terjadi atau dialami oleh perempuan manapun dan harus dilaporkan kepada pihak berwenang tanpa memandang latar belakang korban.

Namun demikian sebagian besar responden masih menunjukkan sikap menyalahkan korban perkosaan dan meragukan kedibilitas korban. Terjadinya perkosaan dikaitkan dengan perilaku atau penampilan korban yang provokatif atau tidak sesuai standar kepatutan bagi seorang perempuan. Korban perkosaan dipandang memiliki karakteristik tertentu (bukan perempuan baik-baik) sehingga 'layak' diperkosa. Pihak korban, bukan pelaku, yang dipandang bertanggungjawab sebagai penyebab perkosaan; sebagai pihak yang menyebabkan pelaku tidak mampu mengontrol dorongan seksualnya terhadap korban. Dalam kenyataannya perkosaan adalah bentuk pemaksaan seksual yang dilakukan pelaku, seringkali dengan ancaman dan menyebabkan setiap perempuan berisiko menjadi korban tanpa memandang latar belakang atau perilakunya. Sikap menyalahkan dan meragukan kredibilitas korban tentu harus dihindari karena dapat menghambat empati dan sensitivitas para profesional dalam pemberian layanan.

Mayoritas responden juga cenderung meremehkan kejadian perkosaan. Pandangan bahwa perkosaan dipandang benar terjadi jika ada perlawanan korban atau dapat digagalkan korban sepanjang korban melakukan perlawanan merefleksikan sikap yang memandang dengan efek fisik dan psikologis yang disebabkan oleh kejadian yang menghambat perlawanan korban. Ketiadaan perlawanan, bahkan oleh perempuan yang sehat sekalipun tidak berarti bahwa korban memang berkehendak diperkosa sehingga harus dipersalahkan. Dalam faktanya perasaan takut, marah dan terancam dapat menyebabkan korban memilih untuk tidak melakukan perlawanan untuk menghindari terjadinya bahaya yang lebih parah yang dapat mengancam keselamatan jiwanya. Selanjutnya sikap ambigu terhadap kredibilitas korban menunjukkan bahwa sebagian responden masih belum yakin bahwa korban adalah pihak yang layak dipercaya dan selayaknya tidak dipersalahkan atas perkosaan yang dialaminya.

Penelitian yang dilakukan oleh Ward dan kawan-kawan terhadap responden mahasiswa di 14 negara Barat (termasuk USA, Jerman, UK) dan non-Barat (khususnya di negaranegara Asia) pada tahun 1992 menemukan gambaran serupa temuan dalam penelitian ini. Sikap mahasiswa Indonesia yang diwakili dalam penelitian ini lebih cenderung sama dengan sikap yang ditunjukkan oleh mahasiswa dari Malaysia, Turki dan India. Sementara mahasiswa dari negara-negara Barat dan Singapura menunjukkan sikap yang cenderung jauh lebih positif terhadap korban kekerasan seksual (Ward et al., 1992). Hal ini perlu menjadi perhatian mengingat bahwa sikap yang ditunjukkan oleh mahasiswa Indonesia saat ini lebih kurang mirip dengan sikap yang dilaporkan oleh mahasiswa di beberapa negara Asia hampir seperempat abad yang lalu.

Penelitian menemukan asosiasi yang signifikan antara sikap terhadap korban perkosaan dengan sikap terhadap peran jender. Semakin egaliter sikap terhadap peran jender, baik di kalangan laki-laki maupun perempuan berasosiasi dengan semakin tingginya penolakan terhadap pernyataan-pernyataan yang menyalahkan atau tidak simpatik terhadap korban serta mendukung pernyataan bahwa pelaku harus bertanggungjawab dan mendapatkan hukuman atas perbuatannya. Sebaliknya semakin tradisional sikap mereka terhadap peran jender maka mereka akan semakin menyalahkan atau memiliki penilaian negatif terhadap korban tindak kekerasan 
Binahayati Rusyidi : Faktor yang Memengaruhi Sikap Mahasiswa terhadap Perempuan Korban Perkosaan

seksual.

Asosiasi sikap terhadap peran jender dan sikap terhadap korban kekerasan seksual konsisten dengan penelitian-penelitian sebelumnya, baik yang dilakukan di dekade 80-an (Burt, 1980) atau era kontemporer sesudahnya di dalam konteks masyarakat Barat maupun Timur (Steinmetz \& Haj-Yahia, 2006; Lee et al., 2007; Talbott et al., 2010; Suarez \& Gadalla, 2010; Lee et al., 2012). Mereka yang mendukung kesetaraan laki-laki dan perempuan akan memandang perkosaan sebagai refleksi dari ketidaksetaraan jender, sebagai bentuk dominasi dan atau kontrol laki-laki atas perempuan. Dalam hal ini, perkosaan sepenuhnya merupakan kesalahan laki-laki sehingga korban yang umumnya perempuan harus mendapat dukungan, bukan dipersalahkan. Perilaku dan cara berpakaian tertentu untuk 'menghindari risiko' diperkosa dipandang sebagai alat kontrol bagi perempuan, sehingga . mereka melanggar kontrol akan dipandang 'layak' untuk menerima konsekuensi negatifnya. Dalam kenyataannya sebagian besar korban perkosaan adalah mereka yang berperilaku dan berpakaian normal sesuai aturan sosial yang berlaku. Sikap menyalahkan korban merupakan manisfestasi pengalihan tanggung jawab perkosaan dari pelaku ke korban.

Asosiasi antara etnisitas dan sikap terhadap perempuan korban kekerasan seksual yang ditemukan dalam penelitian ini juga konsisten dengan beberapa studi sejenis yang dilakukan di luar Indonesia. Namun demikian mayoritas penelitian-penelitian tersebut memfokuskan perbedaan antara ras kelompok kulit hitam dan kulit putih Amerika atau Asia dengan Kaukasia (Mulliken, 2006; Baldwi-White \& EliasLambert, 2016) dan bukan antar kelompok etnik dalam satu kelompok ras seperti yang dikaji dalam penelitian ini. Temuan bahwa mahasiswa dengan latar belakang budaya Sunda menunjukkan sikap yang lebih negatif terhadap korban tindak kekerasan seksual dibandingkan dengan mahasiswa non Sunda tidak dapat dijelaskan secara memadai dalam penelitian ini mengingat keterbatasan dukungan penelitian serupa sebelumnya. Asumsi peneliti bahwa ada faktor-faktor lain yang dapat menjelaskan asosiasi tersebut, misalnya terkait latar belakang sosial ekonomi keluarga atau tingkat pendidikan orangtua, dan sebagainya, namun sayang tidak diuji dalam kajian ini. Untuk itu studi lanjut diperlukan untuk lebih menggali asosiasi antara etnisitas dan sikap terhadap korban perkosaan.

Tingkat relijiusitas merupakan prediktor yang signifikan dalam temuan ini. Hal ini sejalan dengan beberapa penelitian serupa di negara-negara lain. Dalam penelitian dengan responden mahasiswa di Lebanon, Rebeiz dan Harb (2010) dan Mulliken (2006) di Amerika Serikat menemukan bahwa semakin tinggi relijiusitas atau semakin fundamentalis sikap keberagamaan maka akan semakin tinggi dukungan terhadap rape myths. Dan sikap yang menyalahkan korban. Responden yang lebih relijius mungkin memiliki keyakinan yang lebih besar bahwa perempuan bertanggungjawab untuk menjaga kesuciannya serta mengontrol ketat perilakunya. Jika perempuan tidak dapat menjaga perilakukunya, seperti keluar malam sendiri, berpakaian seksi, permisif dalam perilaku seksual atau bertingkah laku provokatif, maka dianggap wajar jika ia menerima konsekuensi seksual atas pelanggaran yang dilakukannya. Hal ini berkebalikan dengan mereka dengan tingkat religiusitas yang lebih rendah yang memiliki pandangan atau standar yang tidak terlalu ketat tentang bagaimana perempuan harus berperilaku.

Penelitian ini tidak menemukan asosiasi signifikan antara jenis kelamin dengan sikap terhadap korban perkosaan. Hal ini sangat kontras terhadap berbagai penelitian sebelumnya di berbagai wilayah termasuk USA, Asia, dan Australia yang konsisten menemukan bahwa perempuan menunjukkan sikap yang lebih berempati terhadap korban dan tidak menyalahkan perempuan yang menjadi korban tindak kekerasan dibandingkan dengan laki-laki (Flood \& Pease, 2009; Newcombe et al., 2008). Namun demikian hal ini tidaklah terlalu mengejutkan mengingat penelitian lain mengenai sikap terhadap istri yang menjadi korban kekerasan dalam rumah tangga di Indonesia juga menemukan bahwa tidak terdapat perbedaan yang signifikan antara sikap responden laki-laki dan perempuan terhadap istri yang menjadi korban kekerasan dalam rumah tangga (Rusyidi, 2011).

Lama studi tidak menjadi prediktor signifikan terhadap sikap mahasiswa, mengindikasikan bahwa proses pendidikan 
Binahayati Rusyidi : Faktor yang Memengaruhi Sikap Mahasiswa terhadap Perempuan Korban Perkosaan

yang diikuti oleh responden belum menjadi media bagi terjadinya perubahan sikap mahasiswa terhadap korban tindak kekerasan seksual. Idealnya, proses pendidikan, yang salah satunya dimanifestasikan oleh lama mengikuti studi tidak hanya dapat meningkatkan pengetahuan dan keterampilan mahasiswa dalam bidangnya tetapi juga kompetensi sikap yang menunjang profesinya. Kondisi ini juga mungkin disebabkan oleh masih terbatasnya keterpaparan mahasiswa dengan perkuliahan dan atau praktikum yang terkait dengan kekerasan berbasis jender dan peran profesi masing-masing dalam penanganan kekerasan berbasis jender.

Dalam penelitian ini, program studi juga tidak menjadi faktor signifikan yang memengaruhi sikap mahasiswa terhadap korban tindak kekerasan seksual. Di satu sisi hal ini merupakan hal yang positif mengingat mahasiswa di ketiga program studi ini sangat berpeluang untuk terlibat dalam penyediaan pelayanan kepada korban tindak kekerasan seksual sehingga mereka diharapkan untuk memiliki sikap yang tepat terhadap korban. Namun demikian di lain sisi perlu dilakukan upaya-upaya khusus untuk mengubah sikap mahasiswa menjadi lebih positif terhadap korban mengingat masih cukup tingginya proporsi mahasiswa di ketiga program studi melaporkan sikap yang negatif terhadap korban.

\section{Simpulan}

Perawat, psikolog dan pekerja sosial merupakan beberapa profesi yang dapat menjadi ujung tombak pemberi layanan bagi perempuan korban tindak kekerasan, termasuk kekerasan seksual. Namun demikian penelitian ini menemukan bahwa secara umum mahasiswa program studi kesejahteraan sosial, keperawatan dan psikologi masih menunjukkan sikap yang kurang positif terhadap perempuan korban tindak kekerasan. Hal ini ditandai dengan masih cukup tingginya sikap yang cenderung menyalahkan korban, menganggap korban bertanggungjawab sebagai penyebab kekerasan seksual yang mereka alami, menganggap remeh kejadian perkosaan dan atau ragu terhadap kredibilitas korban. Selain itu masih ditemukan sikap yang ambivalen yang menunjukkan keragu-raguan sikap. Kondisi-kondisi ini dapat mengurangi keberpihakan, sensitivitas dan empati terhadap korban sehingga akan menghambat proses pemberian bantuan/layanan yang efektif. Sikap yang kurang mendukung tersebut berpotensi untuk terus dimiliki sampai mereka lulus dari program pendidikan dan menjalankan praktek profesinya kecuali jika dilakukan upaya-upaya terstruktur untuk mengubahnya menjadi lebih positif.

Sikap terhadap peran jender, etnisitas dan tingkat keberagaman merupakan faktor-faktor yang memengaruhi sikap mahasiswa terhadap perempuan korban perkosaan. Temuan ini konsisten dengan temuan-temuan penelitian sebelumnya yang dilakukan di berbagai negara. Dengan demikian upaya-upaya untuk meningkatkan sikap para mahasiswa perlu memperhatikan faktor-faktor yang dianggap signifikan tersebut.

Temuan penelitian ini mengimplikasikan pentingnya peran lembaga pendidikan tinggi untuk megakses, mendiskusikan, dan merekonstruksi secara kritis dan proporsional tentang prasangka atau anggapan yang tidak terbukti kebenarannya terkait perkosaan, korban perkosaan, dan pelaku perkosaan di kalangan mahasiswa. Materi perkuliahan dan praktikum terkait kekerasan berbasis jender dan pembahasan peran masing-masing profesi dalam mencegah dan menangulangi kekerasan berbasis jender tampaknya perlu diintegrasikan ke dalam kurikulum. Di dalam program studi keperawatan misalnya, pengintegrasian bahasan kesehatan dan kekerasan berbasis jender sebagai materi pengajaran perlu dilakukan.

Selain itu, pengembangan sikap yang positif dapat disinergikan dalam berbagai mata kuliah lainnya seperti etika profesi dan pendidikan agama serta kegiatan-kegiatan kemahasiswaan yang membangun sensitivitas dan daya kritis mahasiswa terhadap ketidaksetaraan jender dan pentingnya perlindungan atau keberpihakan terhadap korban perlu dikembangkan atau diperkuat. Sikap mahasiswa terhadap peran jender dalam penelitian ini berada pada level menengah, mengindikasikan belum terlalu kuatnya sikap yang mendukung kesetaraan status dan peran laki-laki dan perempuan dalam kehidupan keluarga dan masyarakat, sehingga perlu 
Binahayati Rusyidi : Faktor yang Memengaruhi Sikap Mahasiswa terhadap Perempuan Korban Perkosaan

diperkuat.

Penelitian juga merekomendasikan agar dilakukan penelitian lanjutan dengan desain yang lebih kuat dan komprehensif. Misalnya, melakukan penentuan sampel secara acak sehingga dapat meningkatkan daya generalisasi hasil penelitian, memperluas cakupan sampel ke program studi lainnya yang berpotensi terlibat dalam penyediaan layanan bagi korban tindak kekerasan seksual (misal: program studi kedokteran, hukum), meneliti berbagai variabel lainnya yang belum dimasukkan dalam penelitian ini namun dipandang berpotensi memengaruhi sikap mahasiswa serta menerapkan penggunaan instrumen social desirability untuk mengontrol kemungkinan respon yang bias.

\section{Daftar Pustaka}

Baldwin-White, A., \& Elias-Lambert, N. (2016). Rape myth acceptance among social work students. Journal of Aggression, Maltreatment \& Trauma, 25(7), 702-720.

Boakye, K.E. (2009). Attitudes toward rape and victims of rape: A test of the feminist theory in Ghana. Journal of Interpersonal Violence, 24(10), 1633-1651.

Burt, M. (1980). Cultural myths and supports for rape. Journal of Personality and Social Psychology, 38, 217-230.

Campbell, R. (2008). The psychological impact of rape victims' experiences with the legal, medical, and mental health systems. American Psychologist, 63, 702-717.

Chen, L.P., Murad, Paris, M.L., Colbenson, K.M., Sattler, A.L., Goranson, E.N., Elamin, M.B., Seime, R.J., Shinozaki, G., Prokop, L.J., \& Zirakzadeh, A. (2010). Sexual abuse $\&$ lifetime diagnosis of psychiatric disorders: Systemic review and meta analysis. Mayo Clinic Proceeding, 85(7), 618-629.

Earnshaw, V.A., Pitpitan, E.V., \& Chaudoir, S.R. (2011). Intended responses to rape as functions of attitudes, attribution of fault, and emotions. Sex Roles, 64(5-6), 382-393.
Flood, M., \& Pease, B. (2009). Factors influencing attitudes to violence against women. Trauma, Violence \& Abuse, 10(2), 125-142.

Foster, C., \& Kidd, G.J. (2014). Acquaintance rape: Associations between rape myths, blame and attitudes towards women. Asian Journal of Humanities and Social Studies, 2(3).

Goldblatt, H. (2009). Caring for abused women: Impact on nurses' professionals and personal life experiences. Journal of Advanced Nursing 65(81), 1645-1654.

Haj-Yahia, M.M. (1998). Beliefs about wife beating among Palestinian women: The Influence of their patriarchal ideology. Violence Against Women, 4, 533-558.

Haj-Yahia, M.M., \& Sadan, E. (2008). Issues in intervention with battered women in collectisist societies. Journal of Marital \& Family Therapy, 34(1), 1-13.

Helmreich, R. L., Spence, J. T., \& Gibson, R. H. (1982). Sex role attitudes 1972-1980. Personality and Social Psychology, 37, 16311644.

Komnas Perempuan. (2013). Kekerasan seksual. Diunduh dari http://www. komnasperempuan.go.id/wp-content/ uploads/2013/12/Kekerasan-Seksual-Kenalidan-Tangani.pdf pada 17 Oktober 2016.

Komnas Perempuan. Lembar fakta catatan tahunan (Catahu) 2016 - 7 Maret 2016. Diunduh dari http://www.komnasperempuan. go.id/lembar-fakta-catatan-tahunan-catahu2016-7-maret-2016/.

Lee, J., Busch-Armendaris, N.B., Kim, J., \& Lim, H. (2007). Attitudes toward date rape among university students in South Korea. Sex Roles, 57(9), 641-649.

Lee, J., Kim, J., \& Lim, H. (2010). Rape myth acceptance among Korean college students: The roles of gender, attitudes toward women and sexual double standard. Journal of Interpersonal Violence, 25(7), 1200-1223. 
Binahayati Rusyidi : Faktor yang Memengaruhi Sikap Mahasiswa terhadap Perempuan Korban Perkosaan

Lee, J., Lee, C., Lee, W. (2012). Attitudes toward women, rape myths, and rape perceptions among male police officers in South Korea. Psychology of Women Quarterly, 36(3), 365-376.

Maier, S.L. (2008). "I have heard horrible stories . . . ": Rape victim advocates" perceptions of the revictimizationof rape victims by the police and medical system. Violence Against Women, 14, 786-808.

Miller, A. K., Amacker, A. M., \& King, A. R. (2011). Sexual victimization history and perceived similarity to a sexual assault victim: A path model of perceiver variables predicting victim culpability attributions. Sex Roles, 64(5-6), 5-6372-381.

Mulliken, B. L. (2006). "Rape myth acceptance in college students: The influence of gender, racial, and religious attitudes." (Dissertation Abstracts International: Section B). The Sciences and Engineering, 66(11-B), 6285.

Newcombe, P.A., Van Den Eynde, J., Hafner, D., \& Jolly, L. (2008). Attributions of responsibility for rape: Differences across familiarity of situation, gender, and acceptance of rape myths. Journal of Applied Social Psychology , 38(7), 1736-1754.

Rebeiz, M.J., \& Herb, C. (2010). Perception of rape and attitudes toward rape women in a sample of Lebanese students. Journal of Interpersonal Violence, 25, 735-752.

Rusyidi, B. (2011). Attitudes toward violence against wives in West Java, Indonesia
(Unpublished Dissertation). School of Social Welfare, State University of New York: Albany, New York, USA.

Steinmetz, S., \& Haj-Yahia, M. M. (2006). Definitions of and beliefs about wife abuse among ultra-Orthodox Jewish men from Israel. Journal of Interpersonal Violence, 21, 525-554.

Suarez, E., \& Gadalla, T.M. (2010). "Stop blaming the victim: A meta-analysis on rape myths. J Interpers Violence, 25(11), 20102035.

Tabachnick, B.G., \& Fidell, L.S. (2007). Using multivariate statistics. Boston: Pearson/Allyn \& Bacon

Talbott, K.K., Neill, K.S., \& Rankin, L.L. (2010). Rape-accepting attitudes of university undergraduate students. Journal of Forensic Nursing, 6(4), 170-179.

Ward, C.A. (1992). The attitudes toward rape victims scale: Psychometric data from 14 countries. Universitat Postdam. Diunduh dari http://citeseerx.ist.psu.edu/viewdoc/downloa $\mathrm{d}$ ?doi $=10.1 .1 .611 .8635 \& \mathrm{rep}=\mathrm{rep} 1 \&$ type $=\mathrm{pdf}$ pada 29 September 2016.

Yllo, K.A., \& Straus, M.A. (1990). Patriarchy and violence against wives: The impact of structural and normative factors. In M. A. Straus \&R. J. Gelles (Eds.), Physical violence in American families: Risk factors and adaptations to violence in 8,145 families (pp. 383-399). New Brunswick, NJ: Transaction. 